\title{
Antioxidant and Hepatoprotective Activities of Strobilanthes kunthianus against Carbon Tetrachloride-Induced Hepatotoxicity in Rats
}

\author{
Geetha Balasubramaniam ${ }^{1,2, *}$, Mahendran Sekar ${ }^{3}$, Maithili Varadarajan ${ }^{4}$, Shrishailappa Badami ${ }^{5}$
}

Geetha Balasubramaniam ${ }^{1,2, *}$, Mahendran Sekar ${ }^{3}$, Maithili Varadarajan ${ }^{4}$, Shrishailappa Badami $^{5}$

'Department of Pharmaceutical Chemistry, Swamy Vivekanandha College of Pharmacy, Elayampalayam, Tiruchengode - 637205, Tamilnadu, INDIA.

2Department of Pharmaceutical Chemistry, JSS College of Pharmacy, JSS Academy of Higher Education and Research, Rocklands, Udhagamandalam - 643001, Nilgiris, Tamilnadu, INDIA.

${ }^{3}$ Department of Pharmaceutical Chemistry, Faculty of Pharmacy and Health Sciences, Universiti Kuala Lumpur Royal College of Medicine Perak, Ipoh - 30450, Perak MALAYSIA.

${ }^{4}$ Department of Pharmacognosy,

Padmavathi College of Pharmacy,

Dharamapuri-635205,

Tamilnadu, INDIA.

${ }^{5}$ Chaitanya Vikas Yoga \& Nature Cure Centre, Rajatgiri, Dharwad -580004, Karnataka, INDIA.

\section{Correspondence}

Prof. Dr. Geetha Balasubramaniam

Department of Pharmaceutical Chemistry, Swamy Vivekanandha College of Pharmacy, Elayampalayam, Tiruchengode -637205 ,

Tamilnadu, INDIA.

Phone no: +91-9629842539;

E-mail: saranblue69@gmail.com

History

- Submission Date: 20-04-2020;

- Review completed: 28-05-2020;

- Accepted Date: 06-07-2020

DOI : 10.5530/pj.2020.12.161

Article Available online http://www.phcogj.com/v12/i5

Copyright

(C) 2020 Phcogj.Com. This is an open access article distributed under the terms of the Creative Commons Attribution 4.0 International license.

\begin{abstract}
Background: Strobilanthes kunthianus Nees T Anders (Neela kurinji) is a shrub in the grasslands of Nilgiris, Western Ghats in India. It is well known for many biological properties including antioxidant. However, there is no in-vivo antioxidant and hepatoprotective activities has been carried out previously on S. kunthianus. Objectives: The present study was aimed to evaluate the antioxidant and hepatoprotective activities of methanolic flower extract of $S$. kunthianus (MFESK) against carbon tetrachloride $\left(\mathrm{CCl}_{4}\right.$ )-induced hepatotoxicity in experimental rats. Materials and Methods: The Wistar rats were divided into six groups comprising six animals to each. Group I was served as normal control and group II as $\mathrm{CCl}_{4}$ treated. Both these groups were received sodium CMC $(0.3 \%, 5 \mathrm{ml} / \mathrm{kg})$. Groups III, IV and V animals were treated with MFESK at different dose levels $(100,150$ and $200 \mathrm{mg} / \mathrm{kg})$. Group $\mathrm{VI}$ was treated with standard silymarin $(100 \mathrm{mg} / \mathrm{kg})$. All these treatments were given orally for eight consecutive days. On the $8^{\text {th }}$ day of treatment, except the normal group I, all the other group of animals from III to $\mathrm{VI}$ were received $\mathrm{CCl}_{4}$ in liquid paraffin $(1: 1,1 \mathrm{ml} / \mathrm{kg}$, i.p., single dose) after $1 \mathrm{~h}$ of the vehicle. On the $9^{\text {th }}$ day, the animals were anesthetized and blood was collected from the abdominal artery, then the serum was separated and used for the biochemical estimations. Serum marker enzymes such as ASAT, ALAT, ALP, TGL, CR, TP, TC, TB and albumin were measured using Ecoline kits by using autoanalyzer. Further, blood serum and the supernatant solution of homogenized liver and kidney were used for the estimation of antioxidant parameters such as CAT, SOD and TBARS by spectrophotometrically. Results: The administration of $\mathrm{CCl}_{4}$ caused a significant increase $(P<0.001)$ in the levels of ASAT, ALAT, ALP, TGL, TC, TB and TBARS and decrease in the levels of CR, TP, Albumin, CAT and SOD in serum. A significant $(P<0.001$ and $P<0.01)$ restoration of these values towards the normal level was observed in all the three tested doses of MFESK. Similar results were observed for CAT, SOD and TBARS in both liver and kidney tissues. These results designated the strong antioxidant and hepatoprotective nature of MFESK. The histopathological investigation of liver and kidney tissues also confirmed the observed activities. Conclusion: These findings afford incitement for the development of a novel hepatoprotective herbal drugs.
\end{abstract}

Key words: Strobilanthes kunthianus, Antioxidant, Carbon tetrachloride, Liver disease, Hepatotoxicity, Hepatoprotective.

\section{INTRODUCTION}

Liver has an essential role in the regulation of physiological processes and most of the hepatic diseases are usually caused by large amount consumption of alcohol, exposure of toxic chemicals, autoimmune disorders and viral related infections. Carbon tetrachloride $\left(\mathrm{CCl}_{4}\right)$, a toxic chemical that can damage liver cells commonly by prompting lipid peroxidation (LPO) and oxidative stress in liver. ${ }^{1-5}$ The mechanism involved in the pathogenesis of hepatic damage prompted by $\mathrm{CCl}_{4}$ is due to LPO and that is initiated by P450 enzyme system to the highly reactive trichloromethyl radicals. ${ }^{6}$ This Trichloromethyl radicals can react with glutathione (GSH) and protein thiols as well. In addition, $\mathrm{CCl}_{4}$ also modifies antioxidant enzymes like glutathione peroxidase $(\mathrm{GPx})$, superoxide dismutase (SOD), glutathione-S-transferase (GST), catalase (CAT), glutathione reductase (GR) and thiobarbituric acid reactive substances (TBARS). Enriched LPO formed during the liver microsomal metabolism of ethanol may leads to cirrhosis and hepatitis. $^{8}$

According to the World Health Organization (WHO) report $^{9}$, around $90 \%$ of the acute hepatitis is mainly due to viruses and now ranked as seventh prominent cause of mortality worldwide. There are five major hepatitis viruses such as type A, B, C, D and E, among these, Hepatitis $\mathrm{B}$ and $\mathrm{C}$ infections often results to chronic liver disease and its complications like cirrhosis and liver cancer. WHO estimated that globally there are 257 million persons with hepatitis B and every year up to 900000 people succumb to hepatitis B-related deaths. Also estimated that 71 million people are infected with hepatitis C globally, and the infection that kills nearly 400000 people in every year. ${ }^{9}$ The antioxidant activity or the inhibition of the generation of free radicals is important in

Cite this article: Balasubramaniam G, Sekar M, Varadarajan M, Badami S. Antioxidant and Hepatoprotective Activities of Strobilanthes kunthianus against Carbon Tetrachloride-Induced Hepatotoxicity in Rats. Pharmacogn J. 2020;12(5):1143-51. 
providing protection against hepatic damage. A wide number of natural products that have been reported to possess the hepatoprotective activity by enhancing antioxidant properties. ${ }^{10}$

There are over 200 species of Strobilanthes nearly all in Asia and over 150 occurs in India, especially in Western Ghats and Nilgiris alone claims more than thirty species. Many of the species flower at longer intervals, usually between six and twelve years and in some even after 35 years. Species of Strobilanthes grow wild on the Nilgiris, ranges between 6000 to 7000 feet. The genus Strobilanthes is known for its numerous biological activities. S. crispus has been used as antidiabetic, anxiolytic, laxative, anti-HIV, antileukemic and hepatoprotective. ${ }^{11-17}$

Strobilanthes kunthianus Nees $\mathrm{T}$ Anders (S. kunthianus, Neela kurinji) is a shrub in the grasslands of Western Ghats in India. The Nilgiris, which literally means the blue mountains got its name from the purplish blue flowers of Neela kurinji that blossoms gregariously once in twelve years. S. kunthianus is well known for its medicinal properties. It was reported to possess many biological activities including anti-inflammatory and anti-osteoarthritic, analgesic, antioxidant, antibioflim, enzyme inhibitor, central nervous depressant, antigiardial, antifungal, antibacterial, antiseptic, antimicrobial, cytotoxicity and protect skin against $\mathrm{UV} \cdot{ }^{18-24}$

Singh et al.$^{20}$ reported in-vitro antioxidant activity of $S$. kunthianus flower extract using DPPH and $\mathrm{H}_{2} \mathrm{O}_{2}$ methods. Other than this preliminary study, there is no report has been found about antioxidant activities of S. kunthianus. However, no work has been carried out on hepatoprotective effect of $S$. kunthianus, though the gene has been reported for the treatment of hepatic disorders. Thus the present study was aimed to evaluate in-vivo antioxidant and hepatoprotective activities of methanolic flower extract of S. kunthianus (MFESK) against $\mathrm{CCL}_{4}$ induced hepatic damage in rats.

\section{MATERIALS AND METHODS}

\section{Instruments and chemicals}

Autoanalyser - Merck Microlab 200, manufactured by M/s Vital Scientific N.V., Darmslandt, Netherlands. Centrifuge - Remi centrifuge and R-8c Laboratory centrifuge, Remi Motors Ltd., Mumbai, India. Homogenizer - Elvenjan homogenizer, Remi Motors Ltd., Mumbai. Rotary Evaporator - Rotavapor R-205, Buchi Laboratory Equipments, Flawil, Switzerland. Spectrophotometer - Shimadzu 160-A UV-VIS, Koyoto, Japan. ASAT, ALAT and ALP diagnostic kits were obtained from Span Diagnostic Ltd., Surat, India. Silymarin was obtained from Ranbaxy India Ltd, New Delhi, India. Ibuprofen was procured from Overseas Pharma, Bangalore, India. Commercial animal feed was purchased from Sai Durga Feeds and Food, Bangalore, India. All the chemicals used were of analytical grade.

\section{Extraction}

The whole plant of S. kunthianus was collected from Thalaikuntha region, near Udhagamandalam, Nilgiris district, Tamilnadu, India. The plant was identified and authenticated at Botanical Survey of India, Coimbatore. The separated flowers of S. kunthianus (500 g) were dried, grinded into a coarse powder form and extracted with 2.51 of methanol in a Soxhlet apparatus for 18-20 h. The obtained methanolic flower extract of $S$. kunthianus (MFESK) was concentrated in a rotary evaporator under reduced pressure at $35-40{ }^{\circ} \mathrm{C}$ and stored at $4{ }^{\circ} \mathrm{C}$ in a refrigerator till further use.

\section{Pharmacological screening}

\section{Animals}

Wistar albino rats weighing 180-220 g were obtained from the animal house of JSS College of Pharmacy, Udhagamandalam, Tamilnadu, India
(JSSSCP/IAEC/PHD/PH.CHEM/02/08-09). All the animals were kept under standard laboratory conditions with $12 \pm 1 \mathrm{~h}$ light-dark cycle. Animals were provided with standard rat feed and water ad libitum.

\section{Acute oral toxicity studies of the MFESK}

It was carried out as per OECD-423 guidelines with $2000 \mathrm{mg} / \mathrm{kg}$ of MFESK were administered (maximum dose) orally to different group of rats comprising 10 in each group. The animals were observed for body weight changes, clinical signs and mortality daily for a period of 15 days. At the end of the study period, all the animals were subjected to gross necropsy.

\section{In-vivo antioxidant and hepatoprotective activities of} MFESK

\section{Preparation of the samples and standard}

The suspension of different concentrations of MFESK and standard silymarin $(100 \mathrm{mg} / \mathrm{ml})$ were prepared in $0.3 \%$ sodium carboxy methyl cellulose (CMC) in distilled water and administered orally to the animals with the help of intragastric catheter.

\section{Procedure}

The rats were divided into six groups, each group covering six animals. Group I was used as normal control and group II was classified as $\mathrm{CCl}_{4}$ treated. Sodium CMC $(0.3 \%, 5 \mathrm{ml} / \mathrm{kg})$ was received in both groups. Animals in groups III, IV and V were treated with MFESK at dose levels of 100, 150 and $200 \mathrm{mg} / \mathrm{kg}$. Group VI animals were treated with $100 \mathrm{mg} / \mathrm{kg}$ of silymarin (Standard drug). All these therapies were orally given for 8 days. On the $8^{\text {th }}$ day of treatment, after $1 \mathrm{~h}$ of the vehicle, MFESK or standard treatments, all animals except the normal group I were received $\mathrm{CCl}_{4}$ in liquid paraffin $(1: 1,1 \mathrm{ml} / \mathrm{kg}$, i.p., single dose).

On the $9^{\text {th }}$ day, the blood was obtained under anaesthetized conditions from the abdominal artery of animals and kept at $4{ }^{\circ} \mathrm{C}$ for $30 \mathrm{~min}$. Serum was isolated by centrifugation and used for biochemical parameter estimation. Serum marker enzymes including ASAT, ALAT, ALP, TGL, CR, TP, TC, TB, and albumin have been determined by autoanalyzer using Ecoline kits. SOD, CAT, and TBARS were obtained by spectrophotometric measurements. ${ }^{25-27}$

Following the collection of blood samples, liver and kidney were excised, rinsed in normal ice-cold saline, followed by cold potassium chloride (0.15 M, pH 7.4), and blotted dry. A $10 \%$ w/v homogeneous Elvenjan homogenizer fitted with Teflon plunger was prepared in a potassium chloride buffer $(0.15 \mathrm{M})$ and centrifuged at $2500 \mathrm{rpm}$ at $4{ }^{\circ} \mathrm{C}$ for $15 \mathrm{~min}$. The supernatants were used both in liver and kidney to measure SOD, CAT, and TBARS. A portion of the tissues in the liver and kidney were fixed in $10 \%$ formalin, cut into $5 \mu \mathrm{m}$ thick sections and stained using hematoxylin-eosin, and histopathological observations were made.

\section{Estimation of antioxidant parameters}

\section{Estimation of CAT}

The potassium phosphate buffer $(2.25 \mathrm{ml}, 65 \mathrm{mM}, \mathrm{pH} 7,8)$ and $100 \mu \mathrm{l}$ of serum or tissue homogeneous or sucrose $(0,32 \mathrm{M})$ were incubated for $30 \mathrm{~min}$ at $25^{\circ} \mathrm{C}$. The reaction was started by adding $\mathrm{H}_{2} \mathrm{O}_{2}(0.65 \mathrm{ml}$, $75 \mathrm{mM}$ ). The absorption changes were measured at $240 \mathrm{~nm}$ for $2-3 \mathrm{~min}$ and $\mathrm{dy} / \mathrm{dx}$ was determined for $1 \mathrm{~min}$ for each assay and the results were expressed as CAT units/mg of tissue. ${ }^{26}$

\section{Estimation of SOD}

The sodium carbonate buffer $(2.8 \mathrm{ml}, 0.05 \mathrm{mM})$ and $0.1 \mathrm{ml}$ of serum or homogeneous tissue or sucrose were incubated at $30{ }^{\circ} \mathrm{C}$ for 45 min. Then, the absorbance was changed to sample at zero. Adding adrenaline solution $(10 \mu \mathrm{l}, 9 \mathrm{mM})$ then triggered the reaction. The 
shift in absorbance during 8-12 min was noted at $480 \mathrm{~nm}$. Throughout the assay the temperature was kept at $30^{\circ} \mathrm{C}$. Similarly, the calibration curve for SOD was prepared by taking $10 \mathrm{unit} / \mathrm{ml}$ as standard solution. One unit of SOD inhibits the auto-oxidation of adrenaline by around $50 \%$. The findings have been expressed as SOD activity unit (U)/mg of tissue. ${ }^{28}$

\section{Estimation of TBARS}

Added serum or tissue homogeneous $(1 \mathrm{ml})$, sodium lauryl sulfate $(0.2 \mathrm{ml}, 8.1 \%), 20 \%$ acetic acid $(1.5 \mathrm{ml}, \mathrm{pH} 3.5)$, and thiobarbituric acid solution ( $1.5 \mathrm{ml}, 0.8 \% \mathrm{w} / \mathrm{v}, \mathrm{pH} 7.4)$. This incubation mixture was made up to $5 \mathrm{ml}$ and then heated for $30 \mathrm{~min}$ in boiling water bath. After refrigeration, the red chromogen was collected and centrifuged for $10 \mathrm{~min}$ at $4000 \mathrm{rpm}$. The supernatant was taken and measured its absorbance at $532 \mathrm{~nm}$. As external standard 1,1,3,3-Tetraethoxy propane (TEP) was used. The findings were expressed as $\mathrm{nM}$ of wet tissue MDA/ $\mathrm{mg}$ or $\mathrm{ml}$ of serum using the molar chromophore extension coefficient $\left(1.56 \times 10^{5} \mathrm{M}^{-1} \mathrm{~cm}^{-1}\right)$. The calibration curve was also prepared for TEP, and the findings were expressed as $\mathrm{nM}$ of tissue $\mathrm{MDA} / \mathrm{mg}^{29}$

$\mathrm{nM}$ of $\mathrm{MDA} / \mathrm{mg}$ of tissue or $\mathrm{ml}$ of serum $=$

$$
\text { OD } \times \frac{\text { Volume of homogenate } \times 100 \times 10^{3}}{1.56 \times 10^{5} \times \text { Volume of MFESK taken }}
$$

\section{Estimation of hepatoprotective parameters}

Biochemical estimations in serum were carried out by using Ecoline diagnostic kits.

\section{Assay of ASAT}

Reagents 1 and 2 of Ecoline diagnostic kit for ASAT were mixed at the ratio of $4: 1$ and the temperature was maintained at $30^{\circ} \mathrm{C}$. To $50 \mu \mathrm{l}$ of the sample, $0.5 \mathrm{ml}$ of the reagent solution was added and mixed. After $1 \mathrm{~min}$, the decrease in absorbance was measured every $\min$ for $3 \mathrm{~min}$ at $340 \mathrm{~nm}$.

Enzyme activity $[\mathrm{U} / \mathrm{I}]=(\Delta \mathrm{A} / \mathrm{min}) \times 2143$

Where, $\Delta \mathrm{A}$ is the decrease in absorbance per min.

\section{Assay of ALAT}

Reagents 1 and 2 of Ecoline diagnostic kit for ALAT were mixed at the ratio of $4: 1$ and the temperature was maintained at $30^{\circ} \mathrm{C}$. To $50 \mu \mathrm{l}$ of the sample, $0.5 \mathrm{ml}$ of the reagent solution was added and mixed. After $1 \mathrm{~min}$, the decrease in absorbance was measured every min for $3 \mathrm{~min}$ at $340 \mathrm{~nm}$.

\section{Enzyme activity $[\mathrm{U} / \mathrm{I}]=(\Delta \mathrm{A} / \mathrm{min}) \times 2143$}

Where, $\Delta \mathrm{A}$ is the decrease in absorbance per min.

\section{Assay of ALP}

Reagents 1 and 2 of Ecoline diagnostic kit for ALP were mixed at the ratio of $4: 1$ and the temperature was maintained thermostat at $30^{\circ} \mathrm{C}$. To $20 \mu \mathrm{l}$ of the sample, $1 \mathrm{ml}$ of the reagent solution was added and mixed. After $1 \mathrm{~min}$, the increase in absorbance was measured every $\min$ for 3 $\min$ at $405 \mathrm{~nm}$.

Enzyme activity $[\mathrm{U} / \mathrm{I}]=(\Delta \mathrm{A} / \mathrm{min})$

Where, $\Delta \mathrm{A}$ is the increase in absorbance per min.

\section{Estimation of total bilirubin (TB)}

Reagent 1 and 2 of Ecoline diagnostic kit were mixed at the ratio of 4:1.
The mixture, known as diazo solution, was maintained at $30^{\circ} \mathrm{C}$. To 50 $\mu \mathrm{l}$ of the sample, $50 \mu \mathrm{l}$ of the diazo solution and $250 \mu \mathrm{l}$ of acceleration solution (mixture of caffeine $5 \%$, sodium benzoate $7.5 \%$ and sodium acetate $12.5 \%$ ) were added and mixed. The reaction mixture was maintained at room temperature. After $1 \mathrm{~h}, 250 \mu \mathrm{l}$ of alkaline Fehling's solution II was added and the reaction mixture was incubated at room temperature for $5 \mathrm{~min}$. The absorbance of the sample and standard were measured against the reagent blank, after $5 \mathrm{~min}$ at $578 \mathrm{~nm}$.

Total Bilirubin $(\mathrm{mg} \%)=\left(\mathrm{A}_{\text {sample }}-\mathrm{A}_{\text {blank }}\right) \times 27.78$

Where, $A_{\text {sample }}$ is absorbance of sample and $A_{\text {blank }}$ is absorbance of the blank.

\section{Estimation of triglycerides (TGL)}

To $0.10 \mathrm{ml}$ of sample or standard triglyceride (supplied by Ecoline diagnostic kit), $1 \mathrm{ml}$ of the reagent was added, mixed well and incubated for $10 \mathrm{~min}$ at $37{ }^{\circ} \mathrm{C}$. The absorbance of sample and standard were measured against reagent blank within $60 \mathrm{~min}$ at $546 \mathrm{~nm}$.

\section{Triglycerides $[\mathrm{mg} / \mathrm{dl}]=\left(\mathrm{A}_{\text {sample }} / \mathrm{A}_{\text {standard }}\right) \times$ Concentration of standard}

\section{Estimation of total cholesterol (TC)}

To $0.10 \mathrm{ml}$ of the sample or standard cholesterol (supplied by Ecoline diagnostic kit), $1 \mathrm{ml}$ of the reagent was added, mixed well and incubated for $5 \mathrm{~min}$ at $37{ }^{\circ} \mathrm{C}$ and the absorbance of sample and standard were measured at $546 \mathrm{~nm}$ within $60 \mathrm{~min}$.

Total Cholesterol $[\mathrm{mg} / \mathrm{dl}]=\left(\mathrm{A}_{\text {sample }} / \mathrm{A}_{\text {standard }}\right) \times$ Concentration of standard Estimation of total protein (TP)

Reagents 1 and 2 of Ecoline diagnostic kit for assay of total protein were mixed at the ratio of $4: 1$ and the temperature was maintained always at $37^{\circ} \mathrm{C}$. To $0.10 \mathrm{ml}$ of sample/standard protein (supplied by Ecoline diagnostic kit), $1 \mathrm{ml}$ of the reagent was added, mixed well and incubated for 1 and $5 \mathrm{~min}$, and the absorbance of the sample and standard were measured within $60 \mathrm{~min}$.

Total Protein $[\mathrm{g} / \mathrm{dl}]=\left(\mathrm{A}_{\text {sample }} / \mathrm{A}_{\text {standard }}\right) \times$ Concentration of standard

\section{Estimation of creatinine (CR)}

Buffer solution and picric acid solution from E-Merck diagnostic kit for creatinine were mixed in the ratio of $1: 1$ and incubated for about $10 \mathrm{~min}$ before use. To $1 \mathrm{ml}$ of this reagent solution, $0.20 \mathrm{ml}$ of sample/standard was added, and mixed well. The absorbance was measured exactly after $1 \mathrm{~min}$ and $5 \mathrm{~min}$ at $492 \mathrm{~nm}$. The concentration of creatinine was calculated by using the following formula.

Creatinine concentration $(\mathrm{mg} / \mathrm{dl})=$

$$
\frac{\mathrm{A}_{2}-\mathrm{A}_{1}}{\text { Ast }_{1}-\mathrm{Ast}_{2}}
$$

$\mathrm{A}_{1}$ and $\mathrm{A}_{2}=$ absorbance of sample after 1 and $5 \mathrm{~min}$

$\mathrm{ASt}_{1}$ and $\mathrm{ASt}_{2}=$ absorbance of standard after 1 and $5 \mathrm{~min}$.

\section{Estimation of albumin}

To $1 \mathrm{ml}$ of the reagent solution from E-Merck diagnostic kit for albumin, $100 \mu \mathrm{l}$ of the sample or standard was added, mixed well and incubated at $37^{\circ} \mathrm{C}$ for $10 \mathrm{~min}$. The absorbance of the sample and standard was measured against the reagent blank solution within 60 $\mathrm{min}$. the concentration of albumin was calculated by using the formula. Albumin $(\mathrm{mg} / \mathrm{dl})=($ As/Astd $) \times$ Concentration of standard As $=$ Absorbance of sample and Astd $=$ Absorbance of standard 


\section{Histopathological studies}

The liver and kidney were dissected out of all the animals on the $9^{\text {th }}$ day of the experiment, cleansed off their surrounding tissues and washed with normal saline. The materials were initially fixed for $48 \mathrm{~h}$ in buffered neutral formalin (10\%) and then for $6 \mathrm{~h}$ in bovine solution. They have been prepared for implanting paraffin. Blocks of paraffin were made and parts taken using microtom at a thickness of $5 \mu \mathrm{m}$ were mounted on microscope slides. Such sections were treated with heamotoxyl and alcoholic eosin, then microscopically analyzed to determine histopathological changes. ${ }^{29}$

\section{Statistical analysis}

The significance of the findings of the in-vivo analysis was analyzed by one-way ANOVA, followed by Tukey-Kramer multiple comparison tests and $\mathrm{P}<0.05$ was considered statistically significant.

\section{RESULTS}

In the acute toxicity studies, MFESK was found to be non-toxic and no mortality was observed up to 15 days when administered independently as a single dose (up to $2000 \mathrm{mg} / \mathrm{kg}$, p.o.) and there were no gross results of necropsy.

The serum levels of hepatic enzymes, such as ASAT, ALAT, ALP and TGL, TC, CR, TB and TBARS used as biochemical parameters for evaluation of early hepatic injury were significantly elevated $(\mathrm{P}<0.001)$ and the levels of TP, albumin, CAT and SOD were significantly decreased $(\mathrm{P}<0.001)$ in the $\mathrm{CCl}_{4}$ treated animals. The treatment of MFESK at 100 , 150 and $200 \mathrm{mg} / \mathrm{kg}$ dose to $\mathrm{CCl}_{4}$ intoxicated rats significantly inhibited the increased levels $(\mathrm{P}<0.001$ and $\mathrm{P}<0.01)$ of ASAT, ALAT, ALP, TGL, TC, TB and TBARS towards to normal control when compared to $\mathrm{CCl}_{4}$ treated animals. There was a significant increase $(\mathrm{P}<0.001)$ in the levels of $\mathrm{CR}, \mathrm{TP}$ and albumin towards the normal control. The high dose at $200 \mathrm{mg} / \mathrm{kg}$ also exhibited a significant reversal $(\mathrm{P}<0.001)$ of all the changes caused by $\mathrm{CCl}_{4}$ administration towards the normal control (Table 1). However, the standard silymarin treatment at $100 \mathrm{mg} / \mathrm{kg}$ showed better result than MFESK.
The $\mathrm{CCl}_{4}$ treatment caused a significant decrease $(\mathrm{P}<0.001)$ in the levels of antioxidant enzymes CAT, SOD, and a significant increase $(\mathrm{P}<0.001)$ in the levels of TBARS in serum, liver and kidney when compared to normal control. The treatment with MFESK at $100 \mathrm{mg} / \mathrm{kg}$ to $\mathrm{CCl}_{4}$ intoxicated rats exhibited a significant reversal $(\mathrm{P}<0.01)$ of $\mathrm{CAT}$, SOD and TBARS in serum, liver and kidney towards the normal level when compared to $\mathrm{CCl}_{4}$ treated. The high dose of MFESK, $200 \mathrm{mg} / \mathrm{kg}$ also produced significant changes $(\mathrm{P}<0.001)$ in all these biochemical parameters when compared to $\mathrm{CCl}_{4}$ treated. The standard silymarin at $100 \mathrm{mg} / \mathrm{kg}$ also produced similar significant $(\mathrm{P}<0.001)$ results, except the TBARS in kidney (Table 2). The MFESK treatment at $200 \mathrm{mg} / \mathrm{kg}$ was found to be almost similar to the standard silymarin in reversing most of the biochemical parameters towards the normal control.

Histopathological examination of liver sections showed normal cellular architecture with distinct hepatic cells, sinusoidal spaces and a central vein in normal control group animals (Figure 1a). The liver sections of the rats of $\mathrm{CCl}_{4}$ treated group showed disarrangement of normal hepatic cells with high degree of damage, characterized by the focal necrosis, bile duct proliferation and centrilobular necrosis (Figure 1b). The sections of the rats treated with MFESK at 100, 150 and 200 $\mathrm{mg} / \mathrm{kg}$ and intoxicated with $\mathrm{CCl}_{4}$ exhibited less bile duct proliferation and centrilobular necrosis when compared to the $\mathrm{CCl}_{4}$ treated group (Figure 1c-e). Dose dependent results were observed and the high dose $(200 \mathrm{mg} / \mathrm{kg})$ showed better liver protection. The sections of the rats treated with standard silymarin at $100 \mathrm{mg} / \mathrm{kg}$ and intoxicated with $\mathrm{CCl}_{4}$ showed almost normal architecture of the liver with few centrilobular fatty changes and bile duct proliferation (Figure 1f).

Kidney sections of normal control group of animals showed normal histological appearance (Figure 2a) and $\mathrm{CCl}_{4}$ treated group exhibited high degree of tubulointerstitial nephritis (Figures $2 b$ ). The sections of MFESK treated group of animals at all the three doses and the standard silymarin treatment groups showed normal histological appearance (Figures 2c-f). These findings clearly designates that the liver and kidney tissues, that were damaged by $\mathrm{CCl}_{4}$ intoxication showed recovery with MFESK and silymarin treatments.

Table 1: Effect of MFESK on biochemical parameters in $\mathrm{CCl}_{4}$-induced toxicity in rats.

\begin{tabular}{|c|c|c|c|c|c|c|c|c|c|c|}
\hline Treatments & $\begin{array}{l}\text { Dose } \\
\mathrm{mg} / \mathrm{kg}\end{array}$ & ASAT & ALAT & ALP & TP & TGL & TC & CR & TB & Albumin \\
\hline Normal control & - & $97.17 \pm 3.27$ & $82.00 \pm 2.21$ & $156.50 \pm 2.98$ & $6.67 \pm 0.21$ & $85.83 \pm 2.21$ & $105.30 \pm 3.40$ & $0.70 \pm 0.04$ & $0.60 \pm 0.04$ & $4.32 \pm 0.14$ \\
\hline $\mathrm{CCl}_{4}$ treated & - & $313.70 \pm 3.99^{c}$ & $230.80 \pm 3.30^{c}$ & $521.30 \pm 3.24^{c}$ & $2.50 \pm 0.22^{c}$ & $204.20 \pm 3.08^{c}$ & $237.70 \pm 3.28^{c}$ & $4.03 \pm 0.15^{c}$ & $1.75 \pm 0.04^{c}$ & $2.48 \pm 0.12^{\mathrm{c}}$ \\
\hline Silymarin $+\mathrm{CCl}_{4}$ & 100 & $109.20 \pm 2.82^{\mathrm{a}}$ & $93.33 \pm 2.25^{\mathrm{a}}$ & $177.80 \pm 3.02^{\mathrm{a}}$ & $6.50 \pm 0.22^{\mathrm{a}}$ & $107.50 \pm 2.41^{\mathrm{a}}$ & $125.50 \pm 3.64^{\mathrm{a}}$ & $1.05 \pm 0.08^{\mathrm{a}}$ & $0.80 \pm 0.04^{\mathrm{a}}$ & $4.02 \pm 0.05^{\mathrm{a}}$ \\
\hline \multirow[t]{3}{*}{$\mathrm{MFESK}+\mathrm{CCl}_{4}$} & 100 & $177.50 \pm 3.30^{\mathrm{a}}$ & $166.30 \pm 3.45^{\mathrm{a}}$ & $255.00 \pm 4.02^{\mathrm{a}}$ & $5.50 \pm 0.22^{\mathrm{a}}$ & $175.70 \pm 2.95^{\mathrm{a}}$ & $182.50 \pm 2.96^{\mathrm{a}}$ & $2.87 \pm 0.07^{\mathrm{a}}$ & $1.45 \pm 0.04^{\mathrm{a}}$ & $3.12 \pm 0.06^{b}$ \\
\hline & 150 & $152.00 \pm 3.14^{\mathrm{a}}$ & $138.50 \pm 2.88^{\mathrm{a}}$ & $230.70 \pm 4.21^{\mathrm{a}}$ & $6.12 \pm 0.17^{\mathrm{a}}$ & $142.00 \pm 2.99^{\mathrm{a}}$ & $153.30 \pm 1.94^{\mathrm{a}}$ & $1.67 \pm 0.10^{\mathrm{a}}$ & $1.22 \pm 0.03^{\mathrm{a}}$ & $3.55 \pm 0.15^{\mathrm{a}}$ \\
\hline & 200 & $126.80 \pm 1.91^{\mathrm{a}}$ & $108.70 \pm 2.96^{\mathrm{a}}$ & $201.70 \pm 4.89^{\mathrm{a}}$ & $6.67 \pm 0.21^{\mathrm{a}}$ & $121.50 \pm 2.26^{a}$ & $134.00 \pm 2.60^{\mathrm{a}}$ & $1.17 \pm 0.09^{\mathrm{a}}$ & $0.83 \pm 0.03^{\mathrm{a}}$ & $4.18 \pm 0.09^{\mathrm{a}}$ \\
\hline
\end{tabular}

Values are given as mean \pm SEM for groups of six animals each; Values are statistically significant at ${ }^{b} \mathrm{p}<0.01,{ }^{\mathrm{a}} \mathrm{p}<0.001$ in $\mathrm{CCl}{ }_{4} \mathrm{Vs}$ treated groups $\&{ }^{c} \mathrm{p}<0.001$ between $\mathrm{CCl}_{4}$ treated Vs normal control group.

Table 2: Effect of MFESK on SOD, CAT and TBARS in $\mathrm{CCl}_{4}$-induced toxicity in rats.

\begin{tabular}{|c|c|c|c|c|c|c|c|c|c|c|}
\hline \multirow{2}{*}{ Treatments } & \multirow{2}{*}{$\begin{array}{c}\text { Dose (mg/ } \\
\mathrm{kg})\end{array}$} & \multicolumn{3}{|c|}{ SOD (Unit/min/mg of tissue) } & \multicolumn{3}{|c|}{ CAT (IU/min/mg of tissue) } & \multicolumn{3}{|c|}{ TBARS ( $\mathrm{n}$ mole of MDA/mg of tissue) } \\
\hline & & Serum & Liver & Kidney & Serum & Liver & Kidney & Serum & Liver & Kidney \\
\hline Normal control & - & $0.36 \pm 0.01$ & $0.38 \pm 0.01$ & $0.29 \pm 0.01$ & $1.35 \pm 0.03$ & $4.12 \pm 0.05$ & $1.26 \pm 0.02$ & $3.49 \pm 0.09$ & $4.48 \pm 0.06$ & $5.64 \pm 0.05$ \\
\hline $\mathrm{CCl}_{4}$ treated & - & $0.17 \pm 0.01^{\mathrm{c}}$ & $0.24 \pm 0.01^{c}$ & $0.12 \pm 0.00^{c}$ & $0.36 \pm 0.01^{\mathrm{c}}$ & $2.27 \pm 0.04^{c}$ & $0.93 \pm 0.02^{c}$ & $4.50 \pm 0.07^{\mathrm{c}}$ & $6.77 \pm 0.06^{c}$ & $7.20 \pm 0.04^{c}$ \\
\hline \multirow{4}{*}{$\begin{array}{c}{ }_{\text {Silymarin }}+\mathrm{CCl}_{4} \\
\mathrm{MFESK}+\mathrm{CCl}_{4}\end{array}$} & 100 & $0.32 \pm 0.01^{\mathrm{a}}$ & $0.34 \pm 0.01^{\mathrm{a}}$ & $0.27 \pm 0.00^{\mathrm{a}}$ & $1.41 \pm 0.01^{\mathrm{a}}$ & $3.72 \pm 0.07^{\mathrm{a}}$ & $1.12 \pm 0.02^{\mathrm{a}}$ & $3.27 \pm 0.06^{\mathrm{a}}$ & $4.74 \pm 0.06^{\mathrm{a}}$ & $5.80 \pm 0.04^{\mathrm{a}}$ \\
\hline & 100 & $0.22 \pm 0.01^{\mathrm{a}}$ & $0.28 \pm 0.00^{\mathrm{b}}$ & $0.18 \pm 0.00^{\mathrm{a}}$ & $1.06 \pm 0.04^{\mathrm{a}}$ & $2.85 \pm 0.05^{\mathrm{a}}$ & $0.97 \pm 0.02^{b}$ & $4.03 \pm 0.03^{\mathrm{a}}$ & $5.78 \pm 0.03^{\mathrm{a}}$ & $6.91 \pm 0.03^{\mathrm{a}}$ \\
\hline & 150 & $0.25 \pm 0.01^{\mathrm{a}}$ & $0.31 \pm 0.00^{\mathrm{a}}$ & $0.22 \pm 0.00^{\mathrm{a}}$ & $1.23 \pm 0.02^{\mathrm{a}}$ & $3.30 \pm 0.06^{\mathrm{a}}$ & $1.10 \pm 0.02^{\mathrm{a}}$ & $3.55 \pm 0.02^{\mathrm{a}}$ & $5.13 \pm 0.04^{\mathrm{a}}$ & $6.08 \pm 0.02^{\mathrm{a}}$ \\
\hline & 200 & $0.31 \pm 0.01^{\mathrm{a}}$ & $0.33 \pm 0.01^{\mathrm{a}}$ & $0.25 \pm 0.01^{\mathrm{a}}$ & $1.29 \pm 0.02^{\mathrm{a}}$ & $3.58 \pm 0.05^{\mathrm{a}}$ & $1.22 \pm 0.01^{\mathrm{a}}$ & $3.42 \pm 0.04^{\mathrm{a}}$ & $4.89 \pm 0.04^{\mathrm{a}}$ & $5.89 \pm 0.02^{\mathrm{a}}$ \\
\hline
\end{tabular}

Values are given as mean \pm SEM for groups of six animals each; Values are statistically significant at ${ }^{b} \mathrm{p}<0.01,{ }^{a} \mathrm{p}<0.001$ in $\mathrm{CCl}_{4} \mathrm{Vs}$ treated groups \& ${ }^{\mathrm{c}} \mathrm{p}<0.001$ between $\mathrm{CCl}_{4}$ treated Vs normal control group. 

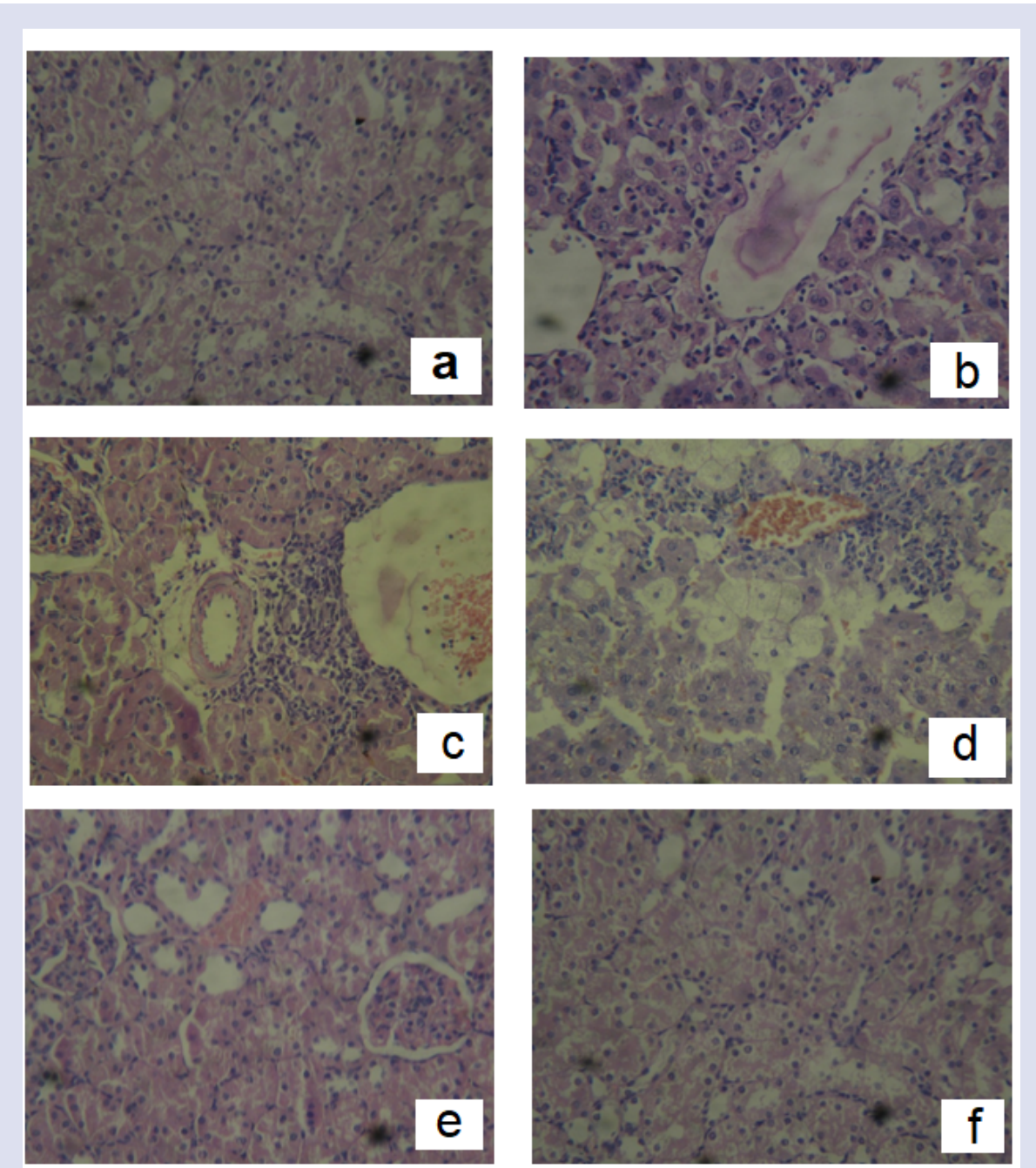

Figure 1: Changes occurred in the histopathology of liver after $\mathrm{CCl}_{4}$ intoxication and prevention by the treatment with MFESK (hematoxylin and eosin, 400x). (a) Normal control (b) $\mathrm{CCl}_{4}$ treated (c) MFESK $(100 \mathrm{mg} / \mathrm{kg})+\mathrm{CCl}_{4}$ (d) MFESK $(150 \mathrm{mg} / \mathrm{kg})+\mathrm{CCl}_{4}$ (e) MFESK $(200 \mathrm{mg} / \mathrm{kg})+\mathrm{CCl}_{4}$ (f) Silymarin $(100 \mathrm{mg} / \mathrm{kg})+\mathrm{CCl}_{4}$

\section{DISCUSSION}

Metabolic processes are primarily controlled by the liver and its disruption contributes to liver injury. ${ }^{30}$ Due to the lack of a trustworthy liver protective medication in the modern medicine system, a variety of herbal formulations are recommended in Ayurveda for the treatment of liver diseases. ${ }^{31}$ Some studies indicate that natural products are considered safe and effective alternative treatments.

In the present study, $\mathrm{CCl}_{4}$ mediated hepatotoxicity was selected as experimental model. Since the changes associated with $\mathrm{CCl}_{4}$ induced liver damage are similar to that of acute viral hepatitis. ${ }^{32}$ The ability of a hepatoprotective drug to lessen the harmful effects or to preserve the normal hepatic physiological mechanisms, which have been distressed by a hepatotoxin, is the index of its protective effects. ${ }^{33}$ Due to its free radical metabolite $\mathrm{CCl}_{3}{ }^{\cdot}$ which alkylates cellular proteins and other macromolecules with a concurrent attack on polyunsaturated fatty acids in the presence of oxygen, the hepatotoxicity induced by $\mathrm{CCl}_{4}$ results in lipid peroxides, resulting in hepatic damage. ${ }^{34}$

Hepatic cells participate in a number of metabolic processes and contain a host of enzymes. ASAT and ALAT are present in tissues at higher concentrations in cytoplasm and ASAT also occurs in mitochondria in particular. In liver injury, the transport mechanism of the hepatocytes is disrupted, resulting in plasma membrane leakage, resulting in an increased serum enzyme level, and subsequent release of soluble enzymes such as ASAT may occur. The elevated serum activities of ASAT and ALAT suggest cell leakage and loss of functional integrity of cell membranes in the liver. ${ }^{35} \mathrm{CCl}_{4}$ administration significantly increased $(\mathrm{P}<0.001)$ the serum level of enzymes such as ASAT and ALAT was observed in rats. Oral administration of MFESK at a dose of $200 \mathrm{mg} / \mathrm{kg}$ resulted in a significant decrease $(\mathrm{P}<0.001)$ in the activity of the above-mentioned enzymes, which can be a consequence of the stabilization of the plasma membrane and the repair of $\mathrm{CCl}_{4}$ damage to the hepatic tissue.

Serum ALP activity was also elevated during administration of $\mathrm{CCl}_{4}$. ALP is usually excreted by the liver through bile. In hepatotoxin liver damage, there is a faulty excretion of bile by the liver which is reflected in their increased serum levels. Hyperbilirubinaemia is a highly sensitive test to substantiate the functional integrity of the liver and the extent of necrosis that increases the binding, conjugation and excretory ability of hepatocytes proportional to the rate of erythrocyte degeneration. ${ }^{36}$ Suppression of ALP activity in the serum of rats treated with MFESK indicates stabilizing biliary dysfunction of rat liver during chronic injury with $\mathrm{CCl}_{4}$.

The rates of TP like albumin would be reduced in hepatotoxic conditions due to defective protein biosynthesis in the liver. ${ }^{37}$ Intoxication with $\mathrm{CCl}_{4}$ induces disturbance and disassociation of polyribosomes on 

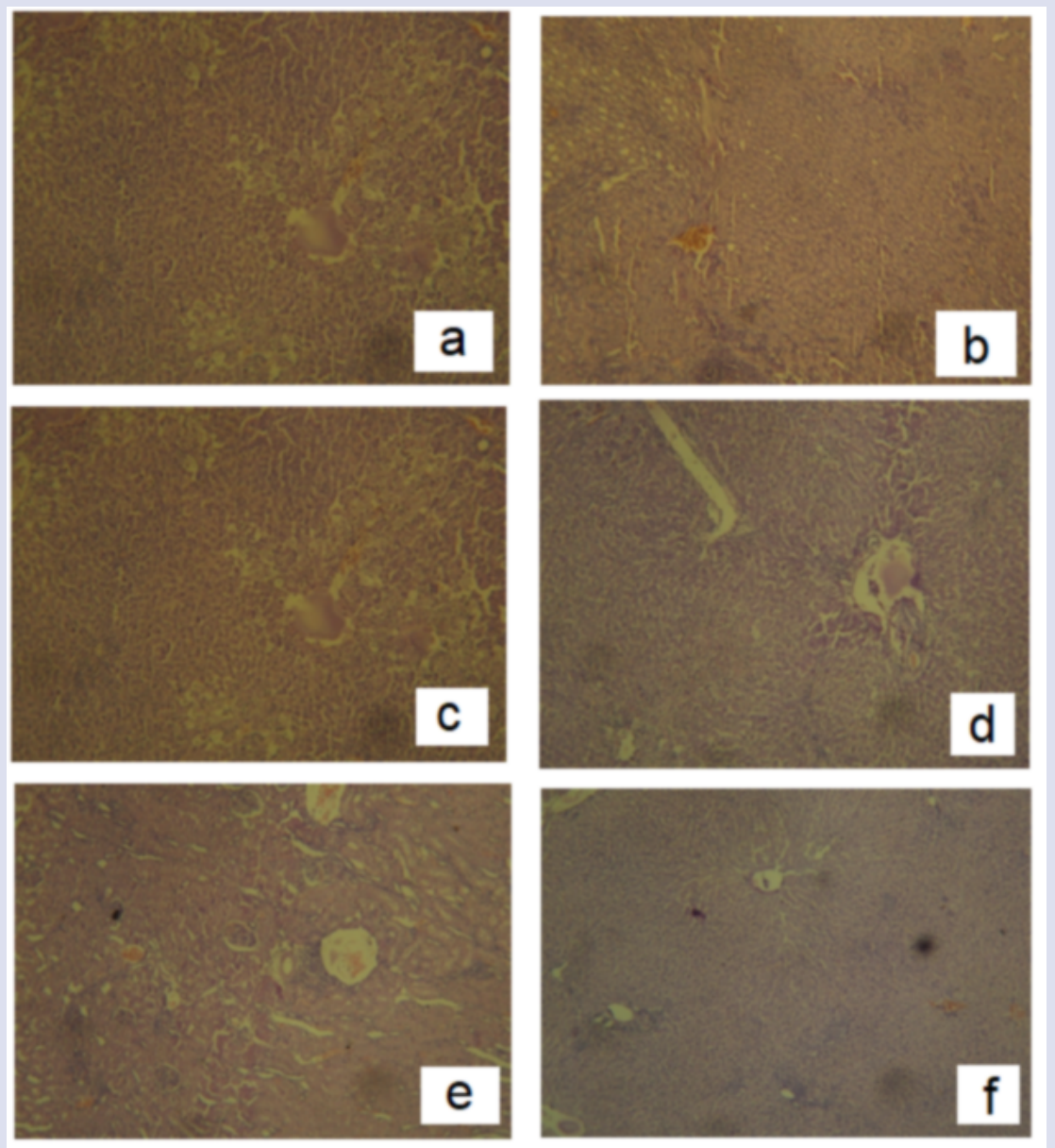

Figure 2: Changes occurred in the histopathology of kidney after $\mathrm{CCl}$ intoxication and prevention by the treatment with MFESK (hematoxylin and eosin, 400x). (a) Normal control (b) $\mathrm{CCl}_{4}$ treated (c) MFESK (100 mg/kg) $+\mathrm{CCl}_{4}$ (d) MFESK $(150 \mathrm{mg} / \mathrm{kg})+\mathrm{CCl}_{4}(\mathrm{e})$ MFESK $(200 \mathrm{mg} / \mathrm{kg})+$ $\mathrm{CCl}_{4}$ (f) Silymarin $(100 \mathrm{mg} / \mathrm{kg})+\mathrm{CCl}_{4}$.

endoplasmic reticulum and thereby decreases protein biosynthesis. MFESK pretreatment preserved the synthesis of the proteins by preserving the polyribosomes.

Hepatocellular damage induces a mild hypertriglyceridemia, due to the metabolic modifications induced by the removal of triglycerides from the liver. ${ }^{38}$ The same is evident in rats caused by the $\mathrm{CCl}_{4}$. There was a significant rise $(\mathrm{P}<0.001)$ in cholesterol in rats caused by $\mathrm{CCl}_{4}$, which may be attributed to the failure of the diseased liver to extract cholesterol from circulation. Pretreatment with MFESK caused a significant dosedependent reversal $(\mathrm{P}<0.001$ and $\mathrm{P}<0.01)$ of the altered levels of TGL and TC toward the normal.

A high serum concentration of TB is an indicator of an increased risk of erythrocyte degeneration. ${ }^{36}$ Because of the liver damage caused by hepatotoxin, there is a deficient excretion of bile by the liver which is expressed in their elevated serum levels. ${ }^{39}$ Pretreatment of MFESK at $200 \mathrm{mg} / \mathrm{kg}$ significantly decreased $(\mathrm{P}<0.001)$ the serum TB level to normal control suggesting improved hepatic capacities.

Hypoalbuminemia is affected by liver diseases and abnormally higher levels of CR indicate the possible breakdown or failure of the kidneys. A significant reversal $(\mathrm{P}<0.001$ and $\mathrm{P}<0.01)$ was observed by the MFESK treatment towards the normal when compared to $\mathrm{CCl}_{4}$ treated animals representing the protection of kidneys by MFESK. It has been recommended that glycogen supports as an energy buffer capable of providing quick and short-range energy. ${ }^{40}$ The elevation of depressed glycogen stores by MFESK in $\mathrm{CCl}_{4}$ treated rats may be attributed to either an inhibition of hepatic glucose output improvement in plasma insulin levels or by synthase responsible for the incorporation of glucose moieties into pre-existing glycogen chains.

Inhibition of free radicals or antioxidant activity is playing a major role in protecting against hepatopathy induced by $\mathrm{CCl}_{4}{ }^{41}$ The human body has an active defensive mechanism to limit and neutralize the free radical damage caused. A group of endogenous antioxidant enzymes such as SOD and CAT are capable of doing this. These enzymes build a compassionate team of defense against ROS in the same way. ${ }^{42}$ In $\mathrm{CCl}_{4}$ induced hepatotoxicity, the stability between ROS development and these antioxidant fortifications may be lost, resulting in 'oxidant stress' which relaxes the cellular functions that lead to hepatic necrosis through a series of events. The hepatic damage in the rats treated with $\mathrm{CCl}_{4}$ was usually determined and suggested based on the reduced SOD and CAT activities. The treated MFESK groups (100, 150 and $200 \mathrm{mg} /$ $\mathrm{kg})$ showed significant increase $(\mathrm{P}<0.001$ and $\mathrm{P}<0.01)$ in the level of these enzymes, which explains their in-vivo antioxidant activity.

The membrane destruction and changes in cellular membrane structure and function were calculated based on the lipid peroxide level. Rise of lipid peroxidation in $\mathrm{CCl}_{4}$ treated rats liver was observed in the current research. The increase of liver MDA levels suggests enriched lipid peroxidation leading to tissue damage and failure of antioxidant defense mechanisms to prevent the production of unwarranted free 
radicals. ${ }^{43}$ Both of these modifications are significantly reversed by MFESK therapies $(\mathrm{P}<0.001)$. Hence, it is possible that the mechanism of hepatoprotection of MFESK may be in line for its antioxidant action.

In the emergence of degenerated nuclei and vacuolated hepatocytes, the $\mathrm{CCl}_{4}$ infected rats had totally lost its natural liver architecture. Fatty shifts, vacuolization, and hepatocyte necrosis in the centrilobular region were significant. $\mathrm{CCl}_{4}$ poisoning resulted in severe confessional development of connective tissue and scar enlargement. Minimal disruption of the hepatocyte structure was observed in rat liver tissue intoxicated with $\mathrm{CCl}_{4}$ and treated with MFESK. $\mathrm{CCl}_{4}$ 's rein parts showed a high degree of tubulointerstitial nephritis compared with normal regulation. Kidney tissue treated with MFESK displayed an almost normal histological appearance suggesting its hepatoprotective function. This findings complimented the findings of biochemical assessments, where a reversal of $\mathrm{CCl}_{4}$ 's effects was observed towards the normal.

Our previous analysis of the constituents present in MFESK included flavonoids, alkaloids, glycosides, phenolics, saponins, steroids, triterpenoids, and tannins. ${ }^{44}$ Therefore, these active constituents could be responsible for such antioxidant and hepatoprotective activities.

\section{CONCLUSION}

The MFESK was significantly restored $(\mathrm{P}<0.001$ and $\mathrm{P}<0.01)$ all the tested parameter values towards the normal, against $\mathrm{CCl}_{4}$ induced liver injury in rats. Similar results were observed for CAT, SOD and TBARS in both liver and kidney tissues. These results indicated strong antioxidant and hepatoprotective effect of MFESK. The histopathological examination of liver and kidney tissues also confirmed these activities. These findings provide incitement for the development of a novel hepatoprotective herbal drugs. There is further scope for research to detect the isolated compounds from MFESK that are responsible for this liver protection. There is also a need to establish the possible mechanism of the observed activities.

\section{CONFLICTS OF INTEREST}

The authors declared that they have no competing interests.

\section{REFERENCES}

1. Recknagel RO. A new direction in the study of carbon tetrachloride hepatotoxicity. Life Sci. 1983;33:401-8.

2. Wendel A, Feuersteins $\mathrm{S}$, Konz KH. Acute paracetamol intoxication of starved mice leads to lipid peroxidation in vivo. Biochem Pharmacol .1987;8:2051-3.

3. Dianzani MU, Muzia G, Biocca ME, Canuto RA. Lipid peroxidation in fatty liver induced by caffeine in rats. Int J Tissue React. 1991;13:79-85.

4. Hiroshi A, Toshlharu $H$, Masahiro $H$, Shoji A. An alteration in liver microsomal membrane of the rat following paracetamol overdose. J Pharm Pharmacol. 1987;39:1047-9.

5. Kodavanti PR, Joshi UM, Young YA, Meydrech EF, Mehendale HM. Protection of hepatotoxic and lethal effects of $\mathrm{CCl} 4$ by partial hepatectomy. Toxicol Pathol. 1989;17:494-505.

6. Demirdag K, Bakcecioglu IH, Ozercan IH, Ozden M, Yilmaz S, Kalkan A. Role of L-carnitine in the prevention of acute liver damage induced by carbon tetrachloride in rats. Journal of Gastroenterol Hepatol. 2004;19:333-8.

7. Anup S, Shivanandappa T. Hepatoprotective effect of the root extract of Decalepis hamiltonii against carbon tetrachloride-induced oxidative stress in rats. Food Chemistry. 2010;118(2):411-7.

8. Smuckler EA. Alcoholic drink: Its production and effects. Fed Process. 1975:34:2038-44

9. World Health Organization (WHO). Regional Office for South-East Asia Regional action plan for viral hepatitis in South-East Asia: 2016-2021. World Health Organization. Regional Office for South-East Asia. 2017. https://apps. who.int/iris/handle/10665/258735

10. Shahjahan M, Sabitha KE, Jainu M, Devi CSS. Effect of Solanum trilobatum against carbon tetrachloride induced hepatic image in albino rats. Indian $J$ Med Res. 2004;120:194-8.

11. Sunarto PA. Materia Medica Indonesia. Penerbitan Directorate Jenderwal Pengawasen Obat dan Makanan Jakarta, 1st Ed.; 1997.
12. Kushumoto JT, Shimadu N, Kakiuchi M, Hattori M, Namba T. Inhibitory effects of Indonesian plant extracts on reverse transcriptase of an RNA tumour virus (I). Phytother Res. 1992;6:241-4.

13. Ismail M, Manickam E, Dania A, Rahmat A, Yahaya A. Chemical composition and antioxidant activity of Strobilanthes crispus leaf extract. J Nut Biochem. 2000;11:536-42.

14. Jaksa S, Rahmat A, Obhman F, Ismail P, Mansor SM. Cancer induction and effect of Strobilanthes crispus leaf extract on liver histology and enzymes changes in rats. J Trop Plants. 2004;5:187-92.

15. Rahmat A, Edvini S, Ismail P,Yunthin T, Abu Bakar M. Chemical constituents, antioxidant activity and cytotoxic effects of essential oil from Strobilanthes inspus and Lawsonia inermis. J Biol Sci. 2006;6:1005-10.

16. Nair RB, Ravishankar B, Vijayan NP, Sasikala CK, Saraswathy VN. Antiinflammatory effect of Strobilanthes heyneanus leaves a biochemical study. J Res Ayurveda and siddha. 1988;9:49-58.

17. Yogespiriya S, Hanachi P, Patimah R, Asmah R, Fanziah O. Histological study during hepatocarciniogenesis in rats treated with Strobilanthes crispus extract. J Biol Sci. 2005;2:153-7.

18. Desu BSR, Elango K, Satish Kumar MN, Suresh B, Manimaran S, Nanjan MJ. In-vitro anti-inflammatory and anti-osteoarthritic activities of Strobilanthes kunthianus and Strobilanthes cuspidatus. Int J Res Pharm Chem. $2011 ; 1(4): 1265-8$

19. Desu BSR, Elango K, Satish Kumar MN, Suresh B, Manimaran S, Nanjan MJ. Analgesic activity of Strobilanthes kunthianus and Strobilanthes cuspidatus. Int J Res Pharm Biomed Sci. 2012;3(1):435-8.

20. Singh BB, Das S, Maithi A. Antioxidant Property for lipophilic extract of Strobilanthes kunthiana flowers. Indian J Res Pharm Biotech. 2014;2(1):1005-9.

21. Everlyne IM, Darsini DTP, Yadav SA. Unraveling antibiofilm potency of Strobilanthes kunthiana Nees T. Anderson ex Benth against throat-infectious methicillin-resistant Staphylococcus aureus. Indo American J Pharma Res. 2016;6(6):5707-16

22. Rajasekaran $A$, Loganathan $\mathrm{V}$, Jaewanth $\mathrm{A}$, Jayakar $\mathrm{B}$. Central nervous activity of Strobilanthes kunthiana leaf. Hamdard Medicus. 2000;43(1):38-40.

23. Singh DN, Verma N, Kulshreshtha DK, Agrawal AK. In-vitro antigiardial activity of ethanolic extract and fractions from Phlebophyllum kunthianum. J Nat Rem. 2012;12(1):68-71.

24. Everlyne IM, Sangilimuthu AY, Darsini DTP. Spectral analyses of the bioactive compounds present in the ethanolic leaf extract of Strobilanthes kunthiana (Nees) T. Anderson ex Benth. Adv Biores. 2015;6(3):65-71.

25. Misra HP, Fridovich I. The role of superoxide dismutase anion in the autooxidation of epinephrine and sample assay in superoxide dismutase. $J$ Biol Chem. 1972;241:3170-5.

26. Beers RF, Jr Sizer IW. A spectrophotometric method for measuring the breakdown of hydrogen peroxide by catalase. J Biol Chem. 1952;195:13340.

27. Ohkawa H, Ohishi N, Yagi K. Assay for lipid peroxides in animal tissue by thiobarbuturic acid reaction. Anal Biochem. 1979;95:351-8.

28. Saggu H, Cooksey J, Dextr D. A selective increase in particulate superoxide dismutase activity in parkinsonian substania nigra. J Neurochem. 1989;53:692-7.

29. Gupta M, Mazumder UK, Sambath Kumar R, Sivakumar T, Vamsi MLM Antitumor activity and antioxidant status of Caesalpinia bonducella against Ehrlich ascites carcinoma in swiss albino mice. J Pharmacol Sci. 2004;94:177 84.

30. Wolf PL. Biochemical diagnosis of liver diseases. Indian J Clin Biochem 1999; 14:59-90.

31. Chatterjee TK. Medicinal plants with hepatoprotective properties. In Herbal Options. $3^{\text {rd }}$ ed. Calcutta: Books and Allied (P) Ltd; 2000. p. 135-7.

32. Suja SR, Latha PG, Pushpangadan P, Rajasekharan S. Evaluation of hepatoprotective effects of Helminthostachys Zeylanica (L.) Hook against carbon tetrachloride induced liver damage in wistar rats. J Ethnopharmacol. 2004;92:61-6.

33. Yadav NP, Dixit VK. Hepatoprotective activity of leaves of Kalanchoe pinnata Pers. J Ethnopharmacol. 2003;86:197-202.

34. Bishayee A, Sarkar A, Chatterjee M. The hepatoprotective activity of carrot (Daucus carota $L$ ) against carbon tetrachloride intoxication in mouse liver. $J$ Ethnopharmacol. 1995;47:69-74

35. Rajesh MG, Latha MS. Protective effect of Glycyrrhiza glabra Linn. on carbon tetrachloride-induced peroxidative damage. Indian J Pharmacol. 2004;36:284-6

36. Singh B, Saxena AK, Chandan BK, Anand KK, Suri OP, SuriSatti KA, et al Hepatoprotective activity of verbenalin on experimental liver damage in rodents. Fitoterapia. 1998;69:134-40.

37. Clawson GA. Mechanism of carbon tetrachloride hepatotoxicity. Pathol Immunopathol Res. 1989:8:104-12. 
38. Glickmann RM, Sebesin SM. Lipid metabolism. In: Asias, I.M., Schachter D, Popper H, Shafritz DA (Eds). Liver Biology and Pathobiology. Raven Press. New York; 1982. p. 123-142.

39. Rao RR. Mechanism of drug induced hepatotoxicity. Indian J Pharmacol. 1973;5:313-8

40. Brown AM. Brain glycogen re-awakened. J Neurochem. 20 04;89:537-52.

41. Castro JA, DeFerreyra EC, DeCastro CR, Fenoes OM, Sasame H, Gillette $J R$. Prevention of carbon tetrachloride induced necrosis by inhibitors of drug metabolism-further studies on their mechanism of action. Biochem Pharmacol. 1974;23:295-302.
42. Amresh G, Kant R, Rao CV, Singh PN. Chemomodulatory influence of Cissampelos pareira (L.) Hirsuta on gastric cancer and antioxidant system in experimental animal. Acta Pharmaceutica Sciencia. 2007;49:71-83.

43. Ashok Shenoy K, Somayaji SN, Bairy KL. Hepatoprotective effects of Ginkgo biloba against carbon tetrachloride induced hepatic injury in rats. Indian J Pharmacol. 2001;33:260-6.

44. Balasubramaniam G, Sekar M, Badami S. Pharmacognostical, physicochemical and phytochemical evaluation of Strobilanthes kunthianus (Acanthaceae). Pharmacogn J. 2020;12(4):731-41.

\section{GRAPHICAL ABSTRACT}

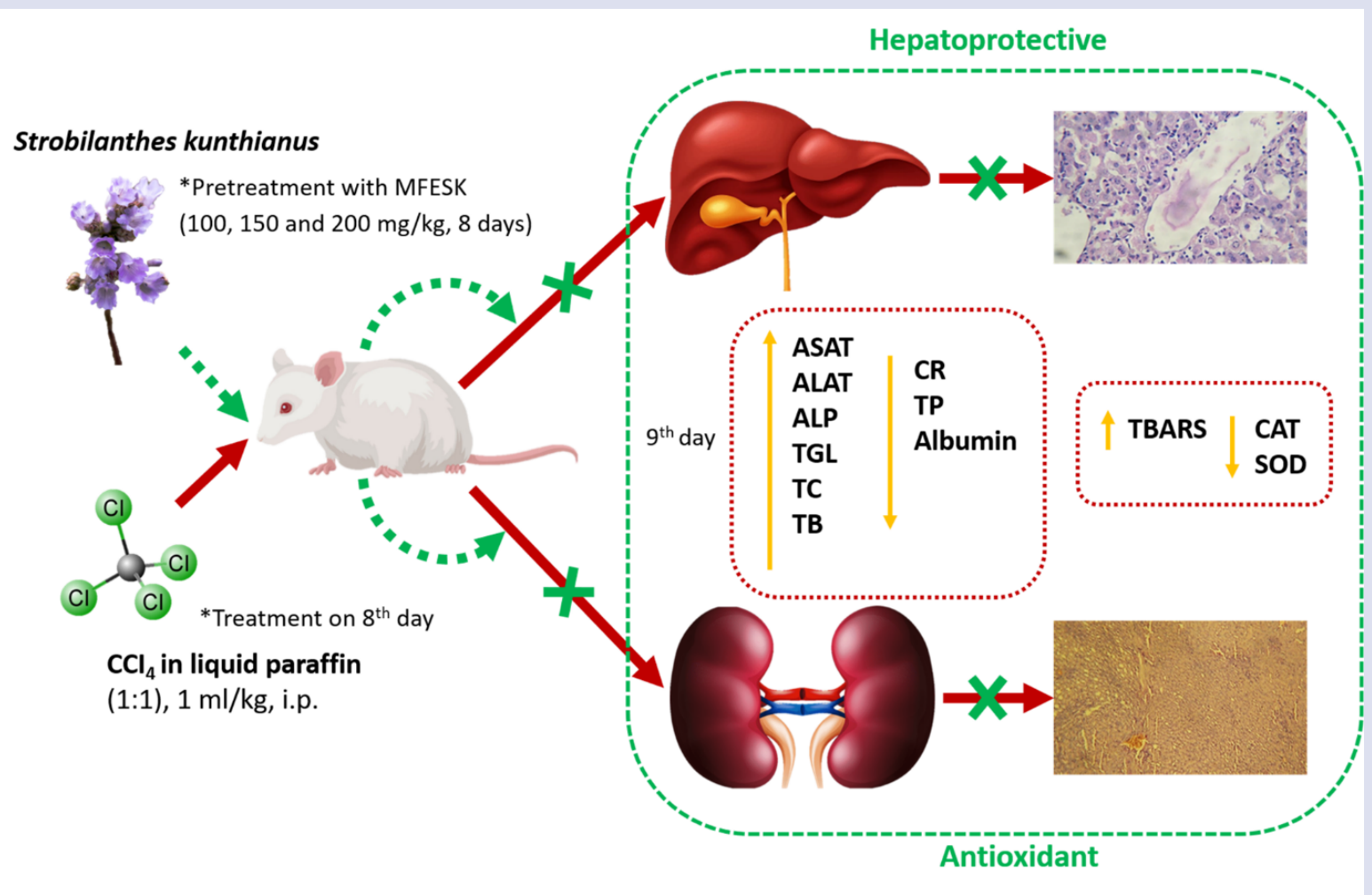

\section{ABOUT AUTHORS}

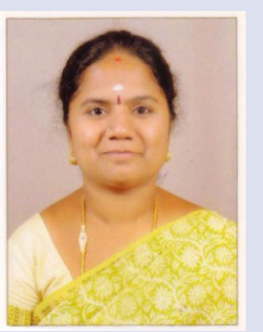

Geetha Balasubramaniam completed her PhD in 2012 at JSS College of Pharmacy, JSS Academy of Higher Education and Research, Udhagamandalam, Tamilnadu, India. She is currently working as a Professor in the Department of Pharmaceutical Chemistry, Swamy Vivekanandha College of Pharmacy, Tamilnadu, India. Her research interest is isolation of active constituents from medicinal plants and study about its biological properties.

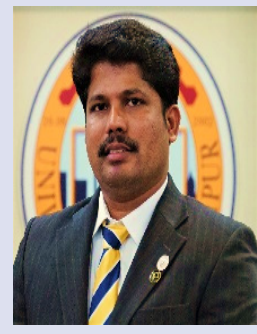

Mahendran Sekar is currently working as Associate Professor in Department of Pharmaceutical Chemistry, Faculty of Pharmacy and Health Sciences, Universiti Kuala Lumpur Royal College of Medicine Perak, Ipoh, Perak, Malaysia. His research is mainly in the field of drug discovery and development of natural products. His research interest is isolation of active constituents from medicinal plants and study about its biological properties. 


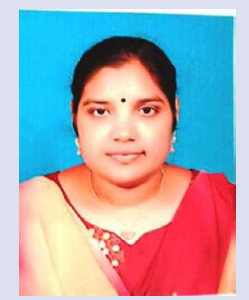

Maithili Varadarajan is currently working as Professor in Department of Pharmacognosy, Padmavathi College of Pharmacy, Dharamapuri, Tamilnadu, India. Her research interest is isolation of active constituents from medicinal plants and study about its biological properties.

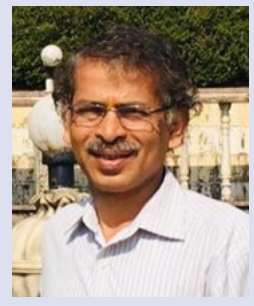

Shrishailappa Badami is currently a proprietor of Chaitanya Vikas Yoga \& Nature Cure Centre, Dharwad, Karnataka, India. His research is mainly in the field of drug discovery and development of natural products. His research interest is isolation of active constituents from medicinal plants and study about its biological properties. At present he is active in manufacturing of herbal products and made it available commercially in the local market.

Cite this article: Balasubramaniam G, Sekar M, Varadarajan M, Badami S. Antioxidant and Hepatoprotective Activities of Strobilanthes kunthianus against Carbon Tetrachloride-Induced Hepatotoxicity in Rats. Pharmacogn J. 2020;12(5):1143-51. 